University of Nebraska - Lincoln

DigitalCommons@University of Nebraska - Lincoln

Publications, Agencies and Staff of the U.S.

Department of Commerce

U.S. Department of Commerce

2010

\title{
Movements of satellite-monitored humpback whales from New Caledonia
}

Claire Garrigue

Ope'ration Ce'tace’s BP 1282798802 Noume’a, New Caledonia, op.cetaus@lagoon.nc

Alexandre N. Zerbini

National Marine Mammal Laboratory, Alaska Fisheries Science Center

Ygor Geyer

Instituto Aqualie, Projeto Monitoramento de Baleias por Sate'lite, Rio de Janeiro, Brazil

Mads-Peter Heide-Jørgensen

Greenland Institute of Natural Resources, P.O. Box 570, 3900 Nuuk, Greenland

Wakao Hanaoka

Greenpeace Japan, N.F Building 2F, 8-13-11, Nishishinjuku, Shinjuku-Ku, Tokyo 160-0023

See next page for additional authors

Follow this and additional works at: https://digitalcommons.unl.edu/usdeptcommercepub

Part of the Environmental Sciences Commons

Garrigue, Claire; Zerbini, Alexandre N.; Geyer, Ygor; Heide-Jørgensen, Mads-Peter; Hanaoka, Wakao; and Clapham, Phil, "Movements of satellite-monitored humpback whales from New Caledonia" (2010). Publications, Agencies and Staff of the U.S. Department of Commerce. 165.

https://digitalcommons.unl.edu/usdeptcommercepub/165

This Article is brought to you for free and open access by the U.S. Department of Commerce at DigitalCommons@University of Nebraska - Lincoln. It has been accepted for inclusion in Publications, Agencies and Staff of the U.S. Department of Commerce by an authorized administrator of DigitalCommons@University of Nebraska - Lincoln. 


\section{Authors}

Claire Garrigue, Alexandre N. Zerbini, Ygor Geyer, Mads-Peter Heide-Jørgensen, Wakao Hanaoka, and Phil Clapham 


\title{
Movements of satellite-monitored humpback whales from New Caledonia
}

\author{
Claire Garrigue*, Alexandre N. Zerbini, Ygor Geyer, Mads-Peter Heide-Jørgensen, Wakao Hanaoka, and \\ Phil Clapham \\ Opération Cétacés BP 1282798802 Nouméa, New Caledonia (CG) \\ South Pacific Whale Research Consortium, Avarua, Rarotonga, Cook Islands (CG, PC) \\ National Marine Mammal Laboratory, Alaska Fisheries Science Center, Seattle, WA 98115-6349, USA (ANZ, PC) \\ Instituto Aqualie, Projeto Monitoramento de Baleias por Satélite, Rio de Janeiro, Brazil (ANZ, YG) \\ Greenland Institute of Natural Resources, P.O. Box 570, 3900 Nuuk, Greenland (M-PH-J) \\ Greenpeace Japan, N.F Building 2F, 8-13-11, Nishishinjuku, Shinjuku-Ku, Tokyo 160-0023, Japan (WH) \\ *Correspondent: op.cetaus@lagoon.nc
}

\begin{abstract}
Knowledge of the local and migratory movements of humpback whales (Megaptera novaeangliae) from New Caledonia is very limited. To investigate this topic, we attached satellite-monitored tags to 12 whales off southern New Caledonia. Tag longevity ranged from 1 to 52 days $(\bar{X}=22.5$ days). Tagged whales generally moved to the south or southeast, with several spending time in a previously unknown seamount habitat named Antigonia before resuming movement, generally toward Norfolk Island or New Zealand. However, 1 female with a calf traveled the entire length of the western coast of New Caledonia $(\sim 450 \mathrm{~km})$ and then west in the direction of the Chesterfield Reefs, a 19th century American ("Yankee") whaling ground. None of the New Caledonia whales traveled to or toward eastern Australia, which is broadly consistent with the low rate of interchange observed from photo-identification comparisons between these 2 areas. The connections between New Caledonia and New Zealand, together with the relatively low numbers of whales seen in these places generally, support the idea that whales from these 2 areas constitute a single population that remains small and unrecovered. DOI: 10.1644/09-MAMM-A-033R.1.
\end{abstract}

Key words: distribution, humpback whale, Megaptera novaeangliae, migration, New Caledonia, Oceania, satellite monitoring

(C) 2010 American Society of Mammalogists

This article is a U.S. government work, and is not subject to copyright in the United States.

Humpback whales (Megaptera novaeangliae) undertake extensive seasonal migrations from summer feeding areas in high latitudes to winter mating and calving grounds in tropical waters (Clapham and Mead 1999; Dawbin 1966). In the Southern Hemisphere, 7 breeding populations are recognized by the International Whaling Commission (International Whaling Commission 1998). These are designated by the letters $\mathrm{A}-\mathrm{G}$, and they have migratory connections to feeding grounds in the Antarctic; these feeding grounds were previously used by the International Whaling Commission as management units, and were labeled Areas I-VI. The relationship between these feeding and breeding areas is known with various degrees of certainty. For example, there is a clear migratory connection between eastern Australia (breeding stock E1) and Area V to the south; similarly, there is good evidence linking western Australia (breeding stock D) with Area IV (International Whaling Commission, in press). The only connection between humpback whales from New
Caledonia (breeding stock E2) has recently been discovered with Area V, using genotyping information (Steel et al. 2008).

Feeding ground connections with breeding areas in Oceania are less clear, as is the degree of movement between different areas in the southwestern South Pacific. Photo-identification studies have shown limited exchange among major island groups including New Caledonia, Tonga, Vanuatu, the Cook Islands, and French Polynesia (Garrigue et al. 2002, in press a). However, the primary migratory destination and winter movements of whales from these locations remain largely undemonstrated.

Given the relative proximity of New Caledonia to eastern Australia, a logical hypothesis is that at least some whales from the former region migrate along the Australian coast to the Antarctic (Area V). A recent study by Garrigue et al. (in

w w w. ma m ma log y. org 
TABLE 1.-Date, deployment location, tag longevity, and summary of satellite locations from humpback whales instrumented with satellite transmitters off New Caledonia in 2007.

\begin{tabular}{|c|c|c|c|c|c|c|}
\hline Transmitter no. & Date deployed & Deployment location & $\begin{array}{l}\text { Tag longevity } \\
\text { (days) }\end{array}$ & $\begin{array}{l}\text { Locations } \\
\text { received }\end{array}$ & $\begin{array}{l}\% \text { of locations of } \\
\text { quality } 1,2 \text {, or } 3\end{array}$ & $\begin{array}{c}\text { Sex }{ }^{\text {a }} \text {-behavior } \\
\text { class }\end{array}$ \\
\hline 24638 & 20 August & $22^{\circ} 27.7^{\prime} \mathrm{S}, 166^{\circ} 50.2^{\prime} \mathrm{E}$ & 26 & 83 & 50 & $\mathrm{~F}$ with calf \\
\hline 24639 & 1 September & $22^{\circ} 23.8^{\prime} \mathrm{S}, 166^{\circ} 46.7^{\prime} \mathrm{E}$ & 44 & 113 & 37 & M \\
\hline 24642 & 10 September & $22^{\circ} 39.9^{\prime} \mathrm{S}, 167^{\circ} 05.7^{\prime} \mathrm{E}$ & 19 & 59 & 19 & $\mathrm{~F}$ \\
\hline 26712 & 27 August & $22^{\circ} 44.7^{\prime} \mathrm{S}, 167^{\circ} 05.2^{\prime} \mathrm{E}$ & 22 & 88 & 39 & M \\
\hline 26715 & 1 September & $22^{\circ} 23.4^{\prime} \mathrm{S}, 166^{\circ} 47.4^{\prime} \mathrm{E}$ & 1 & 9 & 33 & M \\
\hline 33000 & 3 September & $22^{\circ} 25.8^{\prime} \mathrm{S}, 166^{\circ} 54.1^{\prime} \mathrm{E}$ & 7 & 22 & 23 & M \\
\hline 33001 & 8 September & $22^{\circ} 29.7^{\prime} \mathrm{S}, 166^{\circ} 56.7^{\prime} \mathrm{E}$ & 14 & 34 & 24 & M \\
\hline 37229 & 10 September & $22^{\circ} 39.4^{\prime} \mathrm{S}, 167^{\circ} 06.2^{\prime} \mathrm{E}$ & 23 & 70 & 31 & $\mathrm{~F}$ \\
\hline 37230 & 11 September & $22^{\circ} 28.9^{\prime} \mathrm{S}, 166^{\circ} 56.5^{\prime} \mathrm{E}$ & 44 & 109 & 44 & F with calf \\
\hline
\end{tabular}

${ }^{\mathrm{a}} \mathrm{F}=$ female, $\mathrm{M}=$ male.

press b) found 4 matches, out of 1,398 individuals, between these 2 areas. However, the 2 populations exhibit major differences in size and apparent recovery. The humpback whale population passing by eastern Australia is large and increasing at a high rate: Noad et al. (2008) estimated its size at 9,683 whales (95\% confidence interval $[95 \% C I]=8,556-10,959)$, with an annual rate of increase of $10.9 \%(95 \% C I=10.5-11.4 \%)$. In contrast, the New Caledonia population is small and relatively static. Garrigue et al. (2004) used photo-identification and genotype-based mark-recapture to estimate the population at 327 (coefficient of variation $[C V]=0.11)$ and $533(C V=0.15)$, respectively, and they suggested that whales from New Caledonia represent a relatively discrete stock that has only minimal interchange with the Australia stock. The great majority of sighting effort in New Caledonia has been in the large southern lagoon (Garrigue and Gill 1994; Garrigue et al. 2001); consequently, little is known about the local movements of these animals through the waters adjacent to the main island.

To investigate movements within and beyond New Caledonia, we attached satellite-monitored transmitters to 12 humpback whales from southern New Caledonia in the austral winter of 2007. The results of this tagging show differing direction of travel, and extensive use of an offshore seamount reef system. They also confirm migratory movements between New Caledonia and New Zealand and the low rate of exchange documented between the former area and eastern Australia.

\section{Materials ANd Methods}

Study area.-New Caledonia is part of Melanesia, situated between $18^{\circ}$ and $23^{\circ} \mathrm{S}$ and between $158^{\circ}$ and $172^{\circ} \mathrm{E}$ just north of the Tropic of Capricorn in the southwestern Pacific Ocean. It consists of 1 main island and 3 groups of smaller ones plus many uninhabited atolls, including Chesterfield Reefs, which was a whaling ground for American whaling ships during the 19th century (Townsend 1935). Grande Terre, the main island of the archipelago, is $400 \mathrm{~km}$ long and $50-80 \mathrm{~km}$ wide and is surrounded by more than $1,600 \mathrm{~km}$ of barrier reef that delineates a lagoon of $24,000 \mathrm{~km}^{2}$.
Surveys of humpback whales were conducted sporadically beginning in 1991 (Garrigue and Gill 1994), and for 3 months (July, August, and September) each austral winter from 1995 to 2007 (Garrigue et al. 2001). The primary study site encompasses approximately $1,000 \mathrm{~km}^{2}$ and is located in the southern portion of the lagoon off the main island.

Whales were identified individually by the unique pattern on the ventral surface of the tail (Katona et al. 1979), and photographs were matched to the existing catalogue of photographs from the long-term study in this region. Some of the tagged whales had been sighted previously in New Caledonia, and the sex of some was known from genetic analysis of biopsy samples.

Tagging.-Between 20 August and 11 September 2007 we attached Argos satellite-monitored tags to 12 humpback whales in the large southern lagoon (Table 1). The tags consisted of the implantable model (Mold 177) of the SPOT 5 transmitter manufactured by Wildlife Computers (Redmond, Washington). Transmitters were attached to a stainless steel anchoring system equipped with foldable barbs and a triangular sharp tip and were programmed to transmit every day during August-October and every other day beginning in November. They also were programmed to provide a daily maximum of 300 transmissions during 2 periods of the day: 0300-0900 and 1500-2100 h GMT. Transmitters were implanted into the left or right flank of the whales in the vicinity of the dorsal fin; the attachment was accomplished by hand with an 8-m pole deployed from a motor boat, using the technique described by Heide-Jørgensen et al. (2006) and Zerbini et al. (2006). All procedures followed guidelines of the American Society of Mammalogists (Gannon et al. 2007), and research was reviewed and permitted by the administration of New Caledonia.

In plotting the subsequent track of the tagged whales, we used all Argos locations qualities (3, 2, 1, 0, A, and B, in order of accuracy-Argos 1990) when looking at fine-scale movements in the wintering grounds. Argos locations were filtered using the R function Trip (Sumner 2006) in order to remove locations that implied unrealistic movements. Removal occurred if travel speed between 2 consecutive locations 


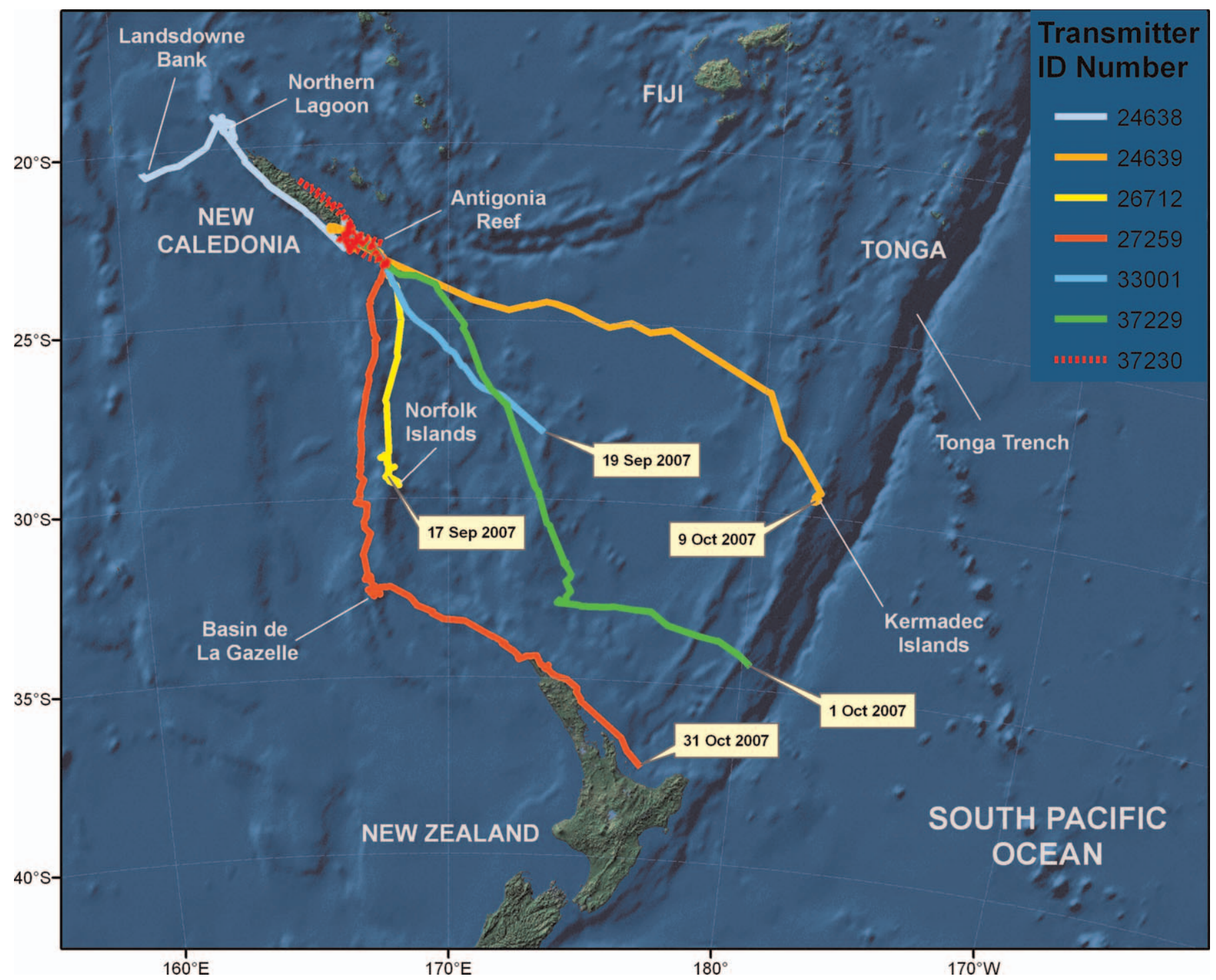

Fig. 1.-Tracks of satellite-monitored humpback whales from New Caledonia, 2007.

exceeded $12 \mathrm{~km} / \mathrm{h}$. This value was selected based on maximum speeds reported for humpback whales (e.g., Mate et al. 1998; Tyack 1983). When looking at movements in the migratory routes and putative feeding destinations, we computed average daily positions from all location qualities (e.g., Zerbini et al. 2006). Instances occurred where only 1 poor-quality location was available in a given day for 2 sequential days; therefore, these were averaged.

\section{Results}

All tagged whales were known or judged from size or behavior to be adults. Photographs of the flukes revealed that 6 of the whales had been identified previously in New Caledonia; 2 were sighted earlier in 2007 prior to the tagging program, and the remaining 4 had been encountered in previous years. One male was observed in 9 different years. Except for 1 whale whose tag worked for only 1 day, all individuals were tracked for between 5 and 52 days $(\bar{X}$ for all 12 whales $=22.5$ days;
Table 1). A total of 924 locations was obtained. All whales were tagged in the same area and all except 2 traveled in a general south-southeast direction, with individual variation (Figs. 1-3).

Whale 24638, a mother accompanied by a calf, stayed in the southern part of the lagoon including off Isle des Pins for 8 days after tagging. It then moved to the great northern lagoon, at the opposite side of the island, navigating outside the western fringing barrier reef in the open ocean and following the reef for 4 days and moving $>400 \mathrm{~km}$. The whale spent 10 days in the northern lagoon before heading southwest and then west for another $300 \mathrm{~km}$ until it reached Landsdowne Bank, $260 \mathrm{~km}$ east of the Chesterfield Reefs, where it remained for at least the next $24 \mathrm{~h}$ before transmissions ceased.

Whale 24639, a male, spent 2 days in the western part of the lagoon before coming back to the southern part, where it remained for 2-3 weeks. During this time it moved back and forth between the southern part of the lagoon and 2 seamounts known as Banc de La Torche and Antigonia, situated $\sim 25$ and $110 \mathrm{~km}$ from the Ile des Pins. Subsequently, the whale 


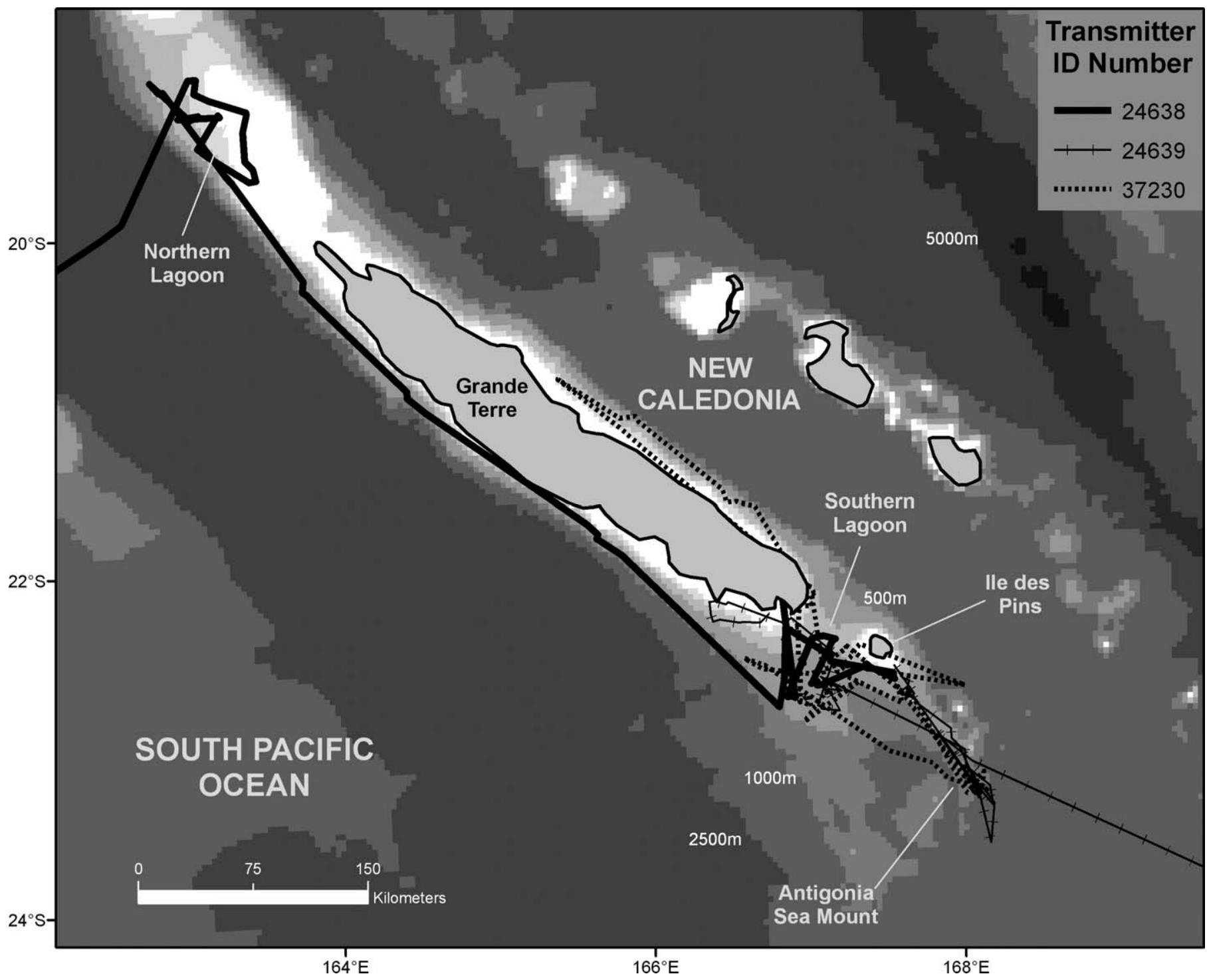

Fig. 2.-Movements of satellite-monitored humpback whales off New Caledonia. Tracks of all whales begin in the southern lagoon where they were tagged. See the text for detailed descriptions of movements.

navigated in a southeasterly direction for 9 days before going southwest for 2 days to reach Raoul Island in the Kermadec group. It remained there $>7$ days before transmissions ceased.

Whale 24641, a male, traveled southeast to Antigonia Reef where it stayed for 10 days before returning northwest. Whale 24642, a female, followed a southeasterly direction, moving back and forth between the 2 seamounts for 2 weeks. It then traveled in a south or southeasterly direction for the 3 remaining days of transmissions.

Whale 26712, a male, spent 2 days in the southern lagoon before starting to move southeast to the 2 seamounts, Banc de la Torche and then Antigonia, where it spent 3 days. This whale left Antigonia heading in a southeasterly then southerly direction for 5 days to the vicinity of Norfolk Island. It remained at Norfolk for at least a week, after which transmissions ceased.

Whale 27258, a male, remained in the lagoon for 4 days then traveled in the direction of Antigonia. Whale 27259 was a mother accompanied by a calf. After being tagged, the mother remained for the day and then over the next 2 days traveled southeast to Antigonia where it stayed for 2 days. This female then left the seamount and traveled south-southwest, then south. The whale passed $70 \mathrm{~km}$ to the west of Norfolk Island but did not stop there, and instead traveled $970 \mathrm{~km}$ over the next 9 days. It then moved erratically for the next 19 days in an area named Basin de La Gazelle, then started to move southeast before reaching the north coast of New Zealand. There, the whale followed the east coast to the Bay of Plenty over the next 8 days.

Whale 33000, a male, traveled southwest toward Antigonia for 7 days. Whale 33001, another male, traveled in a southeasterly direction through Banc de La Torche and Antigonia but maintained this direction for 13 days before transmissions ceased. Whale 37229, a female, also traveled south-southeast for 12 days. The animal then milled around in an open, pelagic area for 6 days before moving off in an easterly or southeasterly direction for 4 days. This was the only whale that passed close to Antigonia but did not stop there. 


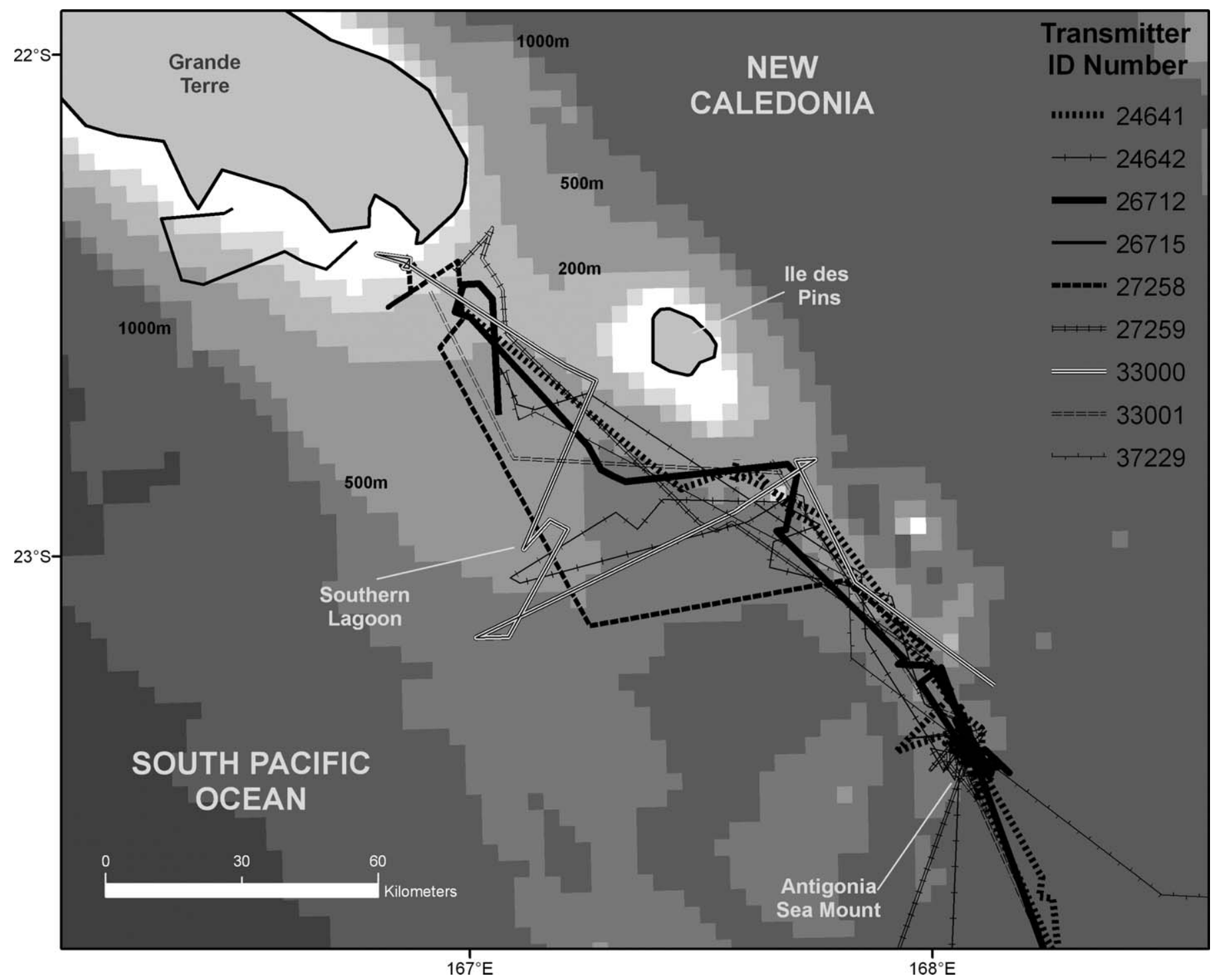

FIG. 3.-Detailed movements of satellite-tagged humpback whales off southern New Caledonia, including the Antigonia Seamount.

Whale 37230 was a female with a small calf. The mother remained in a protected area of the southern lagoon for 4 days. After this it left the lagoon to travel northeast along the eastern coast of New Caledonia, probably outside of the barrier reef. After 2 days of transit it entered the eastern lagoon and changed direction, traveling southeast inside the lagoon back to the southern lagoon, arriving 2 days later. The mother remained in the southern lagoon for another 11 days before traveling southeast in the direction of the seamounts. The whale went back and forth between these seamounts and the southern lagoon for the next 12 days, then moved back to Antigonia where it stayed for the remaining 8 days of transmissions.

\section{Discussion}

Impact of tagging.- - Long-term monitoring of tagged humpback whales has indicated no significant effect of tagging on the animals. S. A. Mizroch (National Marine Mammal Laboratory, Seattle, Washington, pers. comm.) tracked 6 tagged (with much larger instruments than were used here) individuals in the 1970s and found resighting records of from 22 to $>30$ years on all of them, with no indications of compromised health or reproduction. In the present study, 1 of the tagged whales was resighted at the Antigonia Seamount on 2 occasions. On 17 September 2008 it was identified in a competitive pod as the principal escort of a mother and calf. It was subsequently resighted the next day as an escort of another mother-calf pair. The whale appeared healthy and exhibited normal behavior and movements. Given the high resighting rate in New Caledonia we likely will be able to monitor the status of tagged whales, and the appearance of the tagging site on the body, in future years.

Intraisland movements and a new habitat.-Tagging in New Caledonia revealed the existence of a previously unknown offshore habitat at Antigonia Seamount. Whales also used Banc de la Torche, but this area was known from previous work. That Antigonia is important to the population is suggested by at least 7 of the 12 tagged whales spending time there, and the final transmissions of the tags on 3 others 
placed them close to this location. A few seamounts occur close to the southern lagoon, but only Antigonia was used by the tagged whales. Prompted by the tag data, an exploratory expedition to the area was conducted in September 2008. More than 100 humpbacks were observed there in 6 days of sighting effort. Whether this area is in use the entire season, or is used as a departure point for a southward migration, remains to be investigated.

Our discovery of this new habitat may have implications for the estimation of abundance of the New Caledonian population, because previous estimates have been based on mark-recapture data collected primarily in the southern lagoon (Garrigue et al. 2004). This area has been the focus of sampling because it was considered the main breeding area of the population; however, given the new results, it is possible that previous estimates were based on an incomplete coverage of the wintering range of this stock, possibly resulting in a biased estimate of the size of the population.

Most of the whales moved south after being tagged. This was expected because tagging took place late in the season when the whales are leaving the southern lagoon. Although whales are occasionally observed as late as November, the peak of the season is considered to be in August (Garrigue et al. 2001).

Tagging also revealed movements along both the eastern and western coasts of New Caledonia by 2 whales, both of them mothers with accompanying calves. Previous studies of humpback whales in New Caledonia concluded that whales could be found all around the island (Garrigue and Gill 1994) but that the highest density of whales occurred in the southern lagoon where most breeding behavior is believed to occur. These studies also suggested that some areas, such as the lagoon of the east coast, could be preferentially used by mothers and calves as a resting area far from competitive group activity.

The longest distance traveled around the island was by the 2 mothers noted above. The ability of whales to use the western lagoon is thought to be very limited. For a few hundred kilometers the fringing barrier reef comes close to land and prevents any use of the lagoon, which is only a few meters deep and is sometimes closed off by reticulated reef. This explains why humpback whales are rarely observed on the west coast, because few people venture outside the reef to the deeper waters that whales use in transit. By following the reef on the seaward side the whales would eventually enter the huge northern lagoon, a remote area with few human inhabitants and, thus, rare opportunistic sightings.

Implications for population structure.-The movements of humpback whales monitored during this study have implications for stock structure. Humpback whales from New Caledonia are believed to be part of the Area V population (Garrigue and Gill 1994). Previously proposed migration routes followed the eastern coast of Australia or passed by New Zealand; however, this question was never resolved because none of the Discovery tags deployed in the vicinity of the Loyalty Islands east of New Caledonia were ever recovered (Dawbin 1964). Of the 12 satellite-monitored whales, only 1 (whale 24638) moved in a westerly direction, reaching Landsdowne Bank in the direction of Chesterfield Reefs. Dawbin and Falla (1949) considered the Chesterfields, situated in the Coral Sea northwest of New Caledonia (about $17-22^{\circ} \mathrm{S}, 157-163^{\circ} \mathrm{E}$ ), the breeding ground of humpback whales passing the eastern coast of Australia. This opinion was based on charts in which the Chesterfield reef complex was identified as an important American ("Yankee") whaling ground (Townsend 1935). Unfortunately, transmissions ceased after 26 days. If the whale continued on its last recorded course it would have reached the eastern Australian coast. Photo-identification has shown only limited exchange between New Caledonia and the eastern coast of Australia. A recent comparison of 1,242 individual whales identified on the eastern coast of Australia with 672 individual whales from Oceania (of which 160 were from New Caledonia) found only 4 movements between New Caledonia and eastern Australia (Garrigue et al., in press b). This is consistent with the satellite tracks. Although some of these tags arguably did not transmit long enough to allow the whales to be tracked to eastern Australia, the tracks of all but whale 24638 did not suggest movement in this direction.

The 7 other individuals whose tags were still working when they began their southern migration headed generally south, with 2 animals appearing to follow a submarine feature, the Norfolk Ridge. Two of these whales were tracked until they reached New Zealand. One (whale 27259) passed along the northeastern coast of the North Island and the 2nd (whale 24639) went to Kermadec Island. Three other tags stopped transmitting with the whales heading in the direction of New Zealand (whale 26712 at $670 \mathrm{~km}$ distance, whale 33001 at $630 \mathrm{~km}$, and whale 37229 at $460 \mathrm{~km}$ ). Together, these provided the 1st evidence of migratory routes followed by humpback whales wintering in New Caledonia.

Connections with New Zealand ( $n=2$ matches) have previously been established by photo-identification (Constantine et al. 2007; Garrigue et al. 2000) but never in the same year. Comparison of photographic data collected in 2006 allowed the identification of a whale 1st observed in August in the southern lagoon of New Caledonia and photographed a month later off Norfolk Island (D. Paton, Southern Cross University, New South Wales, Australia, pers. comm.). To date, 2 photo-identification matches between New Caledonia and the island of Vanuatu, and 7 matches with Tonga, have been made. The New Zealand population was considerably depleted by commercial whaling. The last whaling stations closed in 1964 following a population collapse, largely precipitated by large-scale, illegal Soviet whaling in Areas $\mathrm{V}$ and VI. Although sightings of humpbacks off New Zealand have increased in recent years (Childerhouse and Gibbs 2005), and the population may be increasing, it clearly remains small. This stands in sharp contrast to the large size of the eastern Australian population, the growth rate of which was most recently estimated at $10.9 \%$ per annum (Noad et al. 2008). The small sizes of the New Caledonian and New Zealand populations strongly suggest a connection between the 2 regions, and this is reinforced by the tagging results reported here. It also is supported by recent genetic analysis of humpback whales from New Zealand that revealed 20 
different mitochondrial DNA haplotypes, all of which had previously been found in New Caledonia (Olavarría et al. 2007). Tagging and whaling data also support a connection between New Caledonia, New Zealand, and Norfolk Island. A coastal fishery in the latter location also collapsed after the Soviet catches, with only 4 whales of a quota of 170 taken in 1962, the last year for the Norfolk station.

\section{ACKnowledgments}

This tagging project was financed primarily by Greenpeace International as part of a scientific collaboration to carry out nonlethal research on specific populations of South Pacific humpback whales. We are very grateful for this vital support of the work. We also thank Fondation d'Entreprise Total and Total Pacifique for their financial support. A. N. Zerbini has been funded by a research fellowship from the United States National Research Council, National Academy of Sciences. The research permit to tag the whales was issued by Province Sud. Janice Waite reviewed and formatted an early draft of the manuscript. Additional comments from 2 anonymous referees are greatly appreciated.

\section{Literature Cited}

Argos. 1990. User's manual. Service Argos, Landover, Maryland.

Childerhouse, S., and N. Gibbs. 2005. Preliminary report for the Cook Strait humpback whale survey winter 2005. Report to the Department of Conservation, Wellington, New Zealand, Paper WGNHO-226957:1-13.

Clapham, P. J., and J. G. Mead. 1999. Megaptera novaeangliae. Mammalian Species 604:1-9.

Constantine, R., K. Russell, N. Gibbs, S. Childerhouse, and C. S. BAKER. 2007. Photo-identification of humpback whales (Megaptera novaeangliae) in New Zealand waters and their migratory connections to breeding grounds of Oceania. Marine Mammal Science 23:715-720.

Dawbin, W. H. 1964. Movements of humpback whales marked in the South West Pacific Ocean 1952 to 1962. Norsk Hvalfangst Tidende 3:68-78.

Dawbin, W. H. 1966. The seasonal migratory cycle of humpback whales. Pp. 145-171 in Whales, dolphins, and porpoises (K. S. Norris, ed.). University of California Press, Berkeley.

Dawbin, W. H., AND R. A. Falla. 1949. A contribution to the study of the humpback whale based on observations at New Zealand shore stations. Proceedings of the Seventh Pacific Science Congress 4:373-382.

Gannon, W. L., R. S. Sikes, and the Animal Care and Use Committee of the American Society of Mammalogists. 2007. Guidelines of the American Society of Mammalogists for the use of wild mammals in research. Journal of Mammalogy 88:809-823.

Garrigue, C., AND P. Gill. 1994. Observations of humpback whales (Megaptera novaeangliae) in New Caledonian waters during 19911993. Biological Conservation 70:211-218.

Garrigue, C., ET AL. 2000. Migratory movement of humpback whales (Megaptera novaeangliae) between New Caledonia, East Australia and New Zealand. Journal of Cetacean Research and Management 2:111-115.

GARRIGUe, C., ET AL. 2002. Movements of humpback whales in Oceania, South Pacific. Journal of Cetacean Research and Management 4:255-260.
GARRIGUE, C., ET AL In press a. Interchange of humpback whales in Oceania (South Pacific). Journal of Cetacean Research and Management.

Garrigue, C., ET AL In press b. First assessment of interchange of humpback whales between Oceania and the east coast of Australia. Journal of Cetacean Research and Management.

Garrigue, C., R. Dodemont, D. Steel, and C. S. Baker. 2004. Organismal and 'gametic' capture-recapture using microsatellites genotyping confirm low abundance and reproductive autonomy of humpback whales on the wintering grounds of New Caledonia. Marine Ecology Progress Series 274:251-262.

Garrigue, C., J. Greaves, and M. Chambellant. 2001. Characteristics of the New Caledonian humpback whale population. Memoirs of the Queensland Museum 47:539-546.

Heide-Jørgensen, M. P., K. L. Laidre, M. V. Jensen, L. Dueck, and L. D. Postma. 2006. Dissolving stock discreteness with satellite tracking: bowhead whales in Baffin Bay. Marine Mammal Science 22:34-45.

International Whaling Commission. 1998. Annex G-report of the Sub-Committee on the Comprehensive Assessment of Southern Hemisphere Humpback Whales. Report of the International Whaling Commission 48:170-182.

InTERnATIONAL Whaling Commission. In press. Report of the Workshop on the Comprehensive Assessment of Southern Hemisphere humpback whales. Journal of Cetacean Research and Management.

Katona, S., B. Baxter, O. Brazier, S. Kraus, J. Perkins, and H. WhITEHEAD. 1979. Identification of humpback whales by fluke photographs. Pp. 33-44 in Behaviour of marine animals (H. E. Winn and B. L. Olla, eds.). Vol. 3. Plenum Press, New York.

Mate, B. R., R. Gisiner, and J. Mobley. 1998. Local and migratory movements of Hawaiian humpback whales tracked by satellite telemetry. Canadian Journal of Zoology 76:863-868.

Noad, M. J., R. A. Dunlop, D. Paton, And D. H. Cato. 2008. An update of the east Australian humpback whale population (E1) rate of increase. Document SC/60/SH31 presented to the Scientific Committee of the International Whaling Commission, Santiago, Chile, June 2008. IWC Secretariat. secretariat@iwcoffice.org. Accessed 1 June 2008.

Olavarría, C., ET AL. 2007. Population structure of humpback whales throughout the South Pacific, and the origin of the eastern Polynesian breeding grounds. Marine Ecology Progress Series 330:257-268.

SteEl, D., et AL. 2008. Migratory connections between humpback whales from South Pacific breeding grounds and Antarctic feeding areas demonstrated by genotype matching. Document SC/60/SH13 presented to the Scientific Committee of the International Whaling Commission, Santiago, Chile, June 2008. IWC Secretariat. secretariat@iwcoffice.org. Accessed 1 June 2008.

Sumner, M. D. 2006. Using Trip—an R package for summarizing animal track data. http://staff.acecrc.org.au/mdsumner/Rutas/ trip-demo.pdf. Accessed 24 August 2009.

TownsEND, C. H. 1935. The distribution of certain whales as shown by $\log$ book records of American whaleships. Zoologica 19:1-50.

TyAck, P. 1983. Differential response of humpback whales, Megaptera novaeangliae, to playback of song or social sounds. Behavioral Ecology and Sociobiology 13:49-55.

Zerbini, A. N., ET AL. 2006. Satellite-monitored movements of humpback whales (Megaptera novaeangliae) in the southwest Atlantic Ocean. Marine Ecology Progress Series 313:295-304.

Submitted 22 January 2009. Accepted 28 April 2009.

Associate Editor was William F. Perrin. 